\title{
A smoke treatment inducing flower formation in iris bulbs
}

\author{
J. A. Schipper \\ Bulb Research Centre, Lisse, Netherlands
}

Accepted: 9 June 1982

Key-words: smoke, iris, flower induction.

\section{Summary}

A smoke treatment stimulated flowering in iris, especially cv. 'Ideal', during early forcing, although fewer leaves than normal were formed. The smoke treatment can be given during the first or second week of the heat treatment.

\section{Introduction}

Iris bulbs can produce flowers the whole year round after storage at high temperatures (de Munk, 1965; Kamerbeek, 1965a). Although flower formation does not take place during storage (Blaauw, 1935), the ability to flower is induced by a heat treatment applied immediately or shortly after lifting of the bulbs. If this treatment is not given, the bulbs remain in a vegetative phase and produce a plant with three or four leaves, which do not form a flower (Kamerbeek, 1965a; Kimura \& Stuart, 1972; Uhring, 1973). Normally flowering plants produce five or more leaves.

After the potential flowering ability is induced by the heat treatment, storage at a lower temperature is obligatory to obtain flower induction and to speed up shoot elongation and leaf extension after planting (Kamerbeek, 1965b).

Each date of planting in different forcing periods demands a specific temperature regime. For early forcing, the heat treatment must be minimal, i.e., 2 weeks at $35^{\circ} \mathrm{C}+3$ days at $40^{\circ} \mathrm{C}$, the subsequent treatment depending on the cultivar (Kamerbeek, 1965b; de Munk, 1965).

Even with temperature treatments, the flowering results can vary from year to year. The variation can be due to soil temperatures during the growing season of the bulbs or to variability within the cultivar stocks.

Spraying of the field crop with 4 litres/ha Luxan Ethrel A led to less flowerbud blasting and fewer three-leaved plants (Durieux \& Kamerbeek, 1974) and the plants had less leaves than those grown from bulbs from an unsprayed crop (Kamerbeek et al., 1980). The spraying method gives more flowering in the planting stock (small bulbs), which is not desired because it reduces the value of the harvested bulbs. Furthermore, spraying the plants with Ethrel may induce gummosis in the bulbs during storage (unpublished data). 


\section{J. A. SCHIPPER}

In the United Kingdom iris bulbs are grown in a two-year cycle. Small bulbs are planted in the first year and are not lifted in the summer; in the following spring, the flowers are cut for sale. When the winter cover of straw is burnt over after the first growing season, a higher percentage of flowering is obtained (Price, 1971). This phenomenon is still unexplained.

Stuart, Asen \& Gould (1966) showed that flowering could be accelerated by exposure of the bulbs to ethylene.

Imanishi (1978) applied either $5 \mathrm{mg} /$ litre ethylene or smoke of smouldering straw to non-flowering bulbs of 'Ideal' and 'Royal Yellow' for 4 days during storage at $25^{\circ} \mathrm{C}$. The smoke treatment resulted in a high percentage of flowering plants.

The aim of the present study was to find out whether the percentage of nonflowering plants and/or of flower-bud blasting during early forcing can be reduced by smoke treatment of the bulbs during the temperature treatment in storage, and to determine the concentration of some gaseous compounds in the smoke.

\section{Materials en methods}

Iris bulbs of 'Ideal', circumference $8-9$ or $10 \mathrm{~cm}$, and of 'Prof. Blaauw', circumference $9-10$ or $11 \mathrm{~cm}$, were given a smoke treatment during the first or second week of storage at $35^{\circ} \mathrm{C}$ after lifting. Each treatment was applied in triplicate, each of these comprising 64 bulbs.

The temperature treatment for 'Ideal' was $2 \mathrm{w} 35^{*}+3 \mathrm{~d} 40+6 \mathrm{w} 9+2 \mathrm{w} 17$ and for 'Prof. Blaauw' $2 \mathrm{w} 35+3 \mathrm{~d} 40+8 \mathrm{w} 9+2 \mathrm{w} 17$.

Smoke treatment was started on 20 August for 'Ideal' and on 27 August for 'Prof. Blaauw'. Three containers with a volume of 50 litres each were stored at $35^{\circ} \mathrm{C}$. In one of these containers, approximately $30 \mathrm{~g}$ of wet wheat straw was burned, and the smoke was conducted to the other two containers, which were filled with bulbs. When enough smoke had reached containers 2 and 3 (visual observation), they were disconnected. This treatment was given once, or repeated daily for 3 or 5 successive days. Air samples were taken from containers 2 and 3 daily during the smoke treatment. These samples were analysed by gas chromatography with flame ionization detectors or a catarometer at the Sprenger Institute (Wageningen) to determine the concentration of $\mathrm{C}_{2} \mathrm{H}_{4}, \mathrm{CO}$, and $\mathrm{O}_{2}$.

The treated bulbs were planted in a glasshouse (Lisse) at a density of 128 bulbs $/ \mathrm{m}^{2}$. Air temperatures were $4 \mathrm{w} 18$ followed by $15^{\circ} \mathrm{C}$ for 'Ideal' and $4 \mathrm{w} 15$ followed by $13^{\circ} \mathrm{C}$ for 'Prof. Blaauw'.

The percentages of flowering, flower-bud blasting, and three-leaf plants were determined, as well as the number of days from planting to flowering (glasshouse days), the length of the stem and the leaves, and the number of leaves per plant.

${ }^{*} \mathrm{w}=$ week; $\mathrm{d}=$ day. $2 \mathrm{w} 35$ means 2 weeks at $35^{\circ} \mathrm{C} ; 3 \mathrm{~d} 40$ means 3 days at $40^{\circ} \mathrm{C}$, etc. 
Table 1. Concentration of $\mathrm{C}_{2} \mathrm{H}_{4}, \mathrm{CO}$ and $\mathrm{O}_{2}$ in the smoke during a smoke treatment applied to iris bulbs for 1,3 , or 5 days in the first and the second week of storage at $35^{\circ} \mathrm{C}$.

\begin{tabular}{lllll}
\hline Week & Day & $\begin{array}{l}\mathrm{C}_{2} \mathrm{H}_{4} \\
(\mu 1 / \text { litre })\end{array}$ & $\begin{array}{l}\mathrm{CO} \\
(\mathrm{ml} / \text { litre })\end{array}$ & $\begin{array}{l}\mathrm{O}_{2} \\
\text { (ml/litre) }\end{array}$ \\
1st & 1 & 902 & 24 & 118 \\
Ist & 2 & 400 & 9 & 96 \\
Ist & 3 & 136 & - & - \\
Ist & 4 & 194 & 4 & 204 \\
Ist & 5 & 258 & 7 & 108 \\
2nd & 1 & 700 & 21 & 116 \\
2nd & 2 & 654 & 21 & 76 \\
2nd & 3 & 325 & - & - \\
2nd & 4 & 361 & 9 & - \\
2nd & 5 & 345 & 8 & 93 \\
\hline
\end{tabular}

-: no observation.

\section{Results}

The results of the gas analyses performed during a 5-day smoke treatment are shown in Table 1. The concentrations of the different gases varied considerably. The concentration of $\mathrm{CO}$ varied with the concentration of $\mathrm{C}_{2} \mathrm{H}_{4}$. No relation could be found between the $\mathrm{O}_{2}$ concentrations and those of the other two gases.

The smoke treatment applied to the bulbs of 'Ideal' decreased the percentage of flower-bud blasting in plants grown from $10-\mathrm{cm}$ bulbs, and also the percentage of three-leaved plants from $8-9 \mathrm{~cm}$ bulbs compared to the controls.

Because no statistically significant differences were found between the smoke treatments applied in the first and second weeks of storage or between the various durations of the treatment, the effects of the smoke treatments are given as average values in Tables 2 and 4.

Table 2. Influence of smoke treatment on the percentage of flowering of 'Ideal' and 'Prof. Blaauw' in bulbs and on the number of glasshouse days, for various grades of planting stock ( $n=64)$.

\begin{tabular}{lllll}
\hline Cultivar & $\begin{array}{l}\text { Grade } \\
(\mathbf{c m})\end{array}$ & Smoke & $\begin{array}{l}\text { Flowering } \\
(\%)\end{array}$ & $\begin{array}{l}\text { Number of } \\
\text { glasshouse days }\end{array}$ \\
'Ideal' & 10 & + & 94 & 58 \\
& 10 & - & 58 & 68 \\
& 8 & + & 77 & 60 \\
'Prof. Blaauw' & 8 & - & 0 & - \\
& 11 & + & 79 & 73 \\
& 11 & - & 84 & 75 \\
& 9 & + & 25 & 81 \\
\hline
\end{tabular}




\section{J.A. SCHIPPER}

Table 3. Percentage of flowering plants with 4, 5, or 6 leaves after smoke treatment of 'Ideal' and 'Prof. Blaauw' iris bulbs.

\begin{tabular}{llllll}
\hline Cultivar & $\begin{array}{l}\text { Grade } \\
(\mathrm{cm})\end{array}$ & Smoke & \multicolumn{2}{l}{ Plants with } & \\
\cline { 3 - 5 } & & & 4 leaves & 5 leaves & 6 leaves \\
'Ideal' & 10 & + & 42 & 58 & 0 \\
& 10 & - & 0 & 80 & 20 \\
'Prof. Blaauw' & 11 & + & - & 8 & 92 \\
& 11 & - & - & 9 & 91 \\
& 9 & + & - & 39 & 61 \\
& 9 & - & - & 36 & 64 \\
\hline
\end{tabular}

An increase in flowering was shown by the smoke-treated bulbs of 'Ideal', and the number of glasshouse days for plants grown from $10-\mathrm{cm}$ bulbs was lower (Table 2). A small beneficial effect of a smoke treatment on flowering was also seen in 'Prof. Blaauw' bulbs of $9-10 \mathrm{~cm}$.

Flower formation in plants of 'Ideal' with a low number of leaves (4) was also stimulated by a smoke treatment (Table 3 ). No stimulation of flower formation by smoke treatment was observed for 'Prof. Blaauw'. Apparently, 'Prof. Blaauw' has to form at least 5 leaves before flower formation can occur.

Earlier flower formation led to a shorter stem and shorter leaves (Table 4), possibly due to the reduced number of internodes per plant.

\section{Discussion}

In irises, flower formation normally takes place after the formation of a certain number of leaves ( 5 or 6 ). After a heat treatment (at least $2 w 35+3 d 40$ ) induction of the formation of a sufficient number of leaves for the formation of an inflorescence occurs in bulbs which would otherwise be too small for flowering. The smaller the bulb, the longer the heat treatment must be to attain a sufficient number of leaves and thus to obtain flowering, but there is a lower limit of bulb size below which flower formation does not occur.

However, the process of leaf and flower induction in response to a heat treatment changes when the exposure to high temperature is combined with a smoke

Table 4. Plant height, leaf length, and the length of the top leaf, of flowering plants with 4,5 , or 6 leaves, grown from 'Ideal' grade 10 bulbs, with and without smoke treatment.

\begin{tabular}{lllll}
\hline Smoke & Number of leaves & $\begin{array}{l}\text { Plant height } \\
(\mathrm{cm})\end{array}$ & $\begin{array}{l}\text { Leaf length } \\
(\mathrm{cm})\end{array}$ & $\begin{array}{l}\text { Length of top leaf } \\
(\mathrm{cm})\end{array}$ \\
+ & & & & \\
+ & 4 & 49 & 43 & 17.5 \\
- & 5 & 54 & 46 & 14.3 \\
- & 5 & 58 & 51 & 16.7 \\
\hline
\end{tabular}


treatment. After this combined treatment, induction of flower formation takes place even when there are fewer leaves than the number normally required.

Because $\mathrm{C}_{2} \mathrm{H}_{4}$, applied to the plants as ethephon, induced more flower formation in bulbs of the same generation, it may be assumed that also in this case $\mathrm{C}_{2} \mathrm{H}_{4}$ present in the smoke influences the flower formation in a positive sense for 'Ideal'. In these experiments, however, an influence of $\mathrm{CO}$ in this respect cannot be excluded. This aspect is under investigation.

Induction of shoot and root growth by exposure to smoke or $\mathrm{C}_{2} \mathrm{H}_{4}$ treatment of bulbs or corms is well known for freesia (Masuda \& Asahira, 1980) and irises (Tsukamoto \& Ando, 1973). The present results show, however, that smoke not only has an effect on rooting and sprouting but also fundamentally influences the induction of flower formation in 'Ideal'. This conclusion holds despite the difference in the reaction of 'Ideal' and 'Prof. Blaauw' to the smoke treatment.

\section{References}

Blaauw, A. H., 1935. De periodieke ontwikkeling van een boliris (Iris xiphium praecox var. Imperator). Verh. K. Acad. Wet. (Sectie 234/3), 1-90.

Durieux, A. J. B. \& Kamerbeek, G. A., 1974. The prevention of three-leaved plants in the forcing of Iris $\times$ hollandica by early heat treatment of stored bulbs or by ethephon field spraying. Scientia Hort. 2: 101-104.

Imanishi, H., 1978. Effects of smoke and ethylene on dormancy breaking and flowering of Freesia corms. Jaarverslag Laboratorium voor Tuinbouwplantenteelt, Wageningen. Gestencild Verslag No. 162: 50 .

Kamerbeek, G. A., 1965a. Temperature treatment of Dutch iris bulbs in relation to the development. Rep. 1st Int. Symp. Iris (Florence, 1963) 459-475.

Kamerbeek, G. A., 1965b. Fysiologie en bloembollenteelt. Meded. Dir. Tuinb. 28, 337-342.

Kamerbeek, G. A., Durieux, A. J. B. \& Schipper, J. A., 1980. An analysis of the influence of Ethrel on flowering of iris cv. 'Ideal': an associated morphogenetic physiological approach. Acta Hort. 109: $235-240$.

Kimura, Y. \& Stuart, N. W., 1972. Exponential nature of heat exposure duration relative to temperature change in the curing and flowering of bulbous iris. J. Am. Soc. hort. Sci. 97: 424-426.

Masuda, M. and Asahira, T., 1980. Effect of ethylene on breaking dormancy of Freesia corms. Scientia Hort. 13: 85-92.

Munk, W. J. de, 1965. All year round culture of Dutch irises. Ann. Rep Jersey Bulbflower Growers Ass. 15-19.

Price, D., 1971. The effects of 'burning over' and fungicidal spraying on iris flower and bulb production and on the incidence of Ink Disease caused by Bipolaris iridis (Oudemans) Dickinson. Exp. Hort. 22: 25-30.

Stuart, N. W., Asen, S. and Gould, Ch. J., 1966. Accelerated flowering of bulbous iris after exposure to ethylene. Hort Sci. 1: 19-20.

Tsukamoto, Y. and Ando, T., 1973. Effect of storage temperature on dormancy and sprouting in Dutch iris bulbs. Environ Control Biol. 11:69-78.

Uhring, J., 1973. Morphological studies of flower bud initiation and development in bulbous iris stored at various temperatures. J. Am. Soc. hort. Sci. 98: 54-61. 